\title{
Developing Materials of Listening Comprehension for the English Department Students
}

\author{
Abdul Qodir \\ abdulqodirjannah@gmail.com \\ Luqman Baehaqi \\ luqmanbae@gmail.com \\ M. Zaini Miftah \\ miftahmzaini@gmail.com \\ State Islamic Institute of Palangka Raya \\ Jl. G. Obos Komplek Islamic Centre, Palangka Raya, Kalimantan Tengah, Indonesia \\ Received: December 31, 2015; Accepted: February 20, 2016; Published: March 25, 2016
}

\begin{abstract}
This study was designed to develop appropriate listening materials based on the needs of users namely the teachers and the students of the English Department of IAIN Palangka Raya. The Research and Development (R\&D) design was applied in this study. The research subjects were four listening instructors and the first-semester students (freshmen) who encountered fourteen meetings of this on-going semester. The findings showed that (1) the stages of the listening materials development such as needs survey, developing materials, expert and instructors validation, revision, try out of materials, revision, and final product; (2) the product is in the form of compact disc recorded materials, an instructor's guide, and a students' worksheet; (3) the product consists of 14 units for semester 1 ; (4) the criteria for selecting materials are based on the existing syllabus and the criteria such as language, content, style of delivery, length, speed of delivery, attractiveness, practicality, level of difficulty and effectiveness; (5) the materials are appropriate for the students since they are relevant to the students' need, interest, and level of students' English ability; and (6) the listening activities can improve the students' motivation to learn English.
\end{abstract}

Keywords: listening, materials, research and development, textbook, processing 
How to cite this paper: Qodir, A., Baehaqi, L., \& Miftah, M. Z. (2016). Developing Materials of Listening Comprehension for the English Department Students. Journal on English as a Foreign Language, 6(1), 1-20.

Listening possesses an essential role in the development of language proficiency (Cahyono, 1997, p. 14). A newborn baby listens to surrounding voices and gradually develops its language ability through ears. However, the most of English teaching course books and methods merely emphasize on productive skills. The relationship between and productive skills and receptive skills is poorly understood (Richards, 2002, p. 235). It leaves the impression that the listening skill to be less important than other language skills. Call (1995) believed that the neglect may stem from the fact that listening is considered a passive skill. Some applied linguists even said that listening skills could be acquired without being taught.

On the contrary, Gebhard (2000) pointed out that listening is an active skill. In two-exchange communication, people are active at the time they respond what they hear or see or agree with an idea. Language learner participates well in oral communication and delivers the meaningful message as long as hethey understands.

Meanwhile, EFL textbooks recently used in the listening classes have been applying top-down listening process. It was shown from the teaching experience of the teachers-researchers in listening class of the English Department at IAIN Palangka Raya. The students have been asked to particular listening skills, for example, listening for gist, listening for the main idea, note taking and listening and summary as what is explained in those textbooks. There were good reasons for this given that students need to be able to listen effectively even when faced with unfamiliar vocabulary or structures. However, if the students understand very few words from the incoming signal, even knowledge about the context may not be sufficient for them to understand the message, and the students can easily get blank in meaning. These situations somehow may lead students to a frustration state and eventually influenced their motivation to improve listening skills.

A preliminary study on the English competence of English Department freshmen students of IAIN Palangka Raya showed that there were numbers of low proficient students with lack vocabulary and weak grammar competence because of inappropriate course-book. The lack of those aspects may lead to difficulties with listening comprehension. Suffered from this inadequacy, the students often 'lost' when listening to English listening text in normal delivery and most of them relied on random guessing to find a correct answer. 
In English Department of IAIN Palangka Raya, listening comprehension course gets equal occasion along with other language skills. It is based on the 2011-set up curriculum of the study program as stated in curriculum document, which focuses on the mastery of listening skills to fulfill one of the requirements of graduate competency standard or Standar Kompetensi Lulusan as stated in the regulation of the Minister of National Education, number 45 of 2002, specifically stated in the Government Regulation, number 19 of 2005. All the graduates are expected to be able to master the discourses in English - language knowledge, language skills, and language components, widely understand the communication process effectively, and master the theory of language acquisition and its implementation in instructional process so that they will be providers of input and linguistic model in the teaching and learning process.

To help the students understand mental and emotional processes in their learning, instructors aided with appropriate teaching materials can guide them in discovering important aspects of the listening process. Recent literature on the teaching of listening indicates the importance of raising students' awareness of the process listening; the process of listening is in line with the listening sequences pitched at different levels (Harmer, 2007, p. 136). A process approach can help students learn how to listen, guiding them through the stages that seem to characterize real-life listening. For the students, after all, teaching materials should reflect effective tips for improving listening comprehension skills and disregard a mere testing of listening.

Related to the previous study on the listening material development for English students, some studies had been carried out. The study of development research in junior and senior high school levels were conducted. First, a development research by Rosyidah (2002) focused on the objective of developing the prototype of listening materials for the teaching of English at senior high school. The results suggest the outline of listening materials of prelistening, whilst listening, and post-listening activities. Second, Zaenuri (2008) conducted a study on developing English as a foreign language listening materials for the students of Islamic junior high school. The finding was the product of listening materials. The final product is in the form of CD recorded materials, an instructor's guide, and a students' worksheet.

Meanwhile, at the university level, some studies had been conducted such as by Adnan (2014). The study focused on listening material development and on investigating the problems and challenges of doing development research which centered on developing the listening materials. Additionally, with a different skill, in speaking skill, Fauzan (2014) carried out the research on developing EFL speaking materials for Islamic university students. 
In this current study, the researchers developed the materials of Listening Comprehension I for the following considerations. First, based on the stages of human development, the students of English Department of IAIN Palangka Raya taking a course of Listening Comprehension I existed at the first semester. At this age, the students underwent the development of their ability to develop the next ability they concern. Last, it seemed that the present study was the basis of the next study. It means that when it is successful in developing the materials of Listening Comprehension I, it will go on developing the materials of the other levels. In this case, as an effort which has to be done developing materials is the course material of Listening Comprehension I for the first-semester students of English Department of IAIN Palangka Raya.

Based on the background of the study, the problem of this study can be stated as follows: "What listening materials are appropriate for the firstsemester students of the English Department of IAIN Palangka Raya?" Meanwhile, the specification of the developed product was practicality, suitability, syllabus, and curriculum based and usability whether in the classroom, language laboratory or outside of class. The products consisted of an instructor's manual, a student's workbook including CD of recorded materials. The instructor's manual covered the guidelines of teaching, the tapescripts, and the answer key. The students' workbook contained the instruction and the tasks.

The developed materials of Listening Comprehension I is limited for the first-semester students of English Department of IAIN Palangka Raya with relatively low English proficiency. The development of the materials adapted several commercially published course books and recorded materials taken from online sources.

The first-semester students of English Department of IAIN Palangka Raya are beginner-level listeners. So, the techniques applied to teach them listening comprehension should match their level. In line with it, Brown (2001) proposes eleven techniques with different goals.

The first five techniques belong to bottom-up exercises: (1) Discriminating between intonation contours in sentences. This goal is marked with one activity, namely listening to a sequence of sentence patterns with either rising or falling intonation then placing a check in column 1 (rising) or column 2 (falling), depending on the pattern the students hear. (2) Discriminating between phonemes. One activity is addressed to this goal, namely listening to pairs of words. Some pairs differ in their final consonant, and some pairs are the same. The students circle the word "same" or "different," depending on what they hear. (3) Selective listening for morphological endings. 
The activities of this goal are first, listening to a series of sentences then circling "yes" if the verb has an -ed ending, and circling "no" if it does not; second, listening to a series of sentences then on the answer they, circling the one (of three) verb forms contained in the sentence that the students hear. (4) Selecting details from the text (Word Recognition).

Five activities can be carried out for the goal. First, matching a word that the students hear with its picture; second, listening to a weather report, looking at a list of words then circling the words that the students hear; third, listening to a sentence that contains clock time then circling the clock time that the students hear among three choices (5:30, 5:45 and 6:15); fourth, listening to an advertisement, selecting the price of an item, then writing the amount on a price tag; and fifth, listening to a series of recorded telephone messages from an answering machine then filling in a chart with the following information from each caller: name, number, time, and message. (5) Listening for normal sentence word order. One activity refers to this goal, namely listening to a short dialogue and filling in the missing words that have been deleted in a partial transcript.

The second three techniques belong to top-down exercises: (1) Discriminating between emotional reactions. The activity to reach the goal is listening to a sequence of utterances then placing a check in the column that describes the emotional reaction that the students hear: interested, happy, surprised, or unhappy. (2) Getting the gist of a sentence. The activity referring to this is listening to a sentence describing a picture then selecting the correct picture. (3) Recognizing the topic. For this, three activities can be done: (1) listening to a dialogue and deciding where the conversation occurred by circling the correct location among three multiple-choice items, (2) listening to a conversation and looking at the pictured greeting cards then deciding which of the greeting cards is sent by writing the greeting under the appropriate card, and (3) listening to a conversation and deciding what the people are talking about by choosing the picture that shows the topic.

The last three techniques refer to interactive exercises: (1) Building a semantic network of word associations. The activity is listening to a word and associating all the related words that come to mind. (2) Recognizing a familiar word and relating it to a category. The activity is listening to words from a shopping list and matching each word to the store that sells it. (3) Following directions did by listening to a description of a route and tracking it on a map.

Some models of developing instructional materials are proposed by experts of instructional design (Zaenuri, 2015, p. 124); namely Tomlinson (1998), Richards (1999), Dick \& Carey (2001), Finney (2002), and Hyland (2003). 
According to Tomlinson (1998), there are seven steps in the process of materials writing. The steps are the identification of the need for materials, exploration of need, the contextual realization of materials, pedagogical realization of materials, production of materials, student use of materials, evaluation of materials against agreed objectives. In addition, Richards (1999) points out that curriculum development processes in language teaching comprise needs analysis, goal setting, syllabus design, methodology, testing, and evaluation.

Dick and Carey (2001) proposed a model of instructional design which is called a systematic instructional design. They offer ten steps i.e. identifying instructional goals, conducting instructional analysis, identifying characteristics of the students, writing performance objectives, developing test items, developing instructional strategies, developing instructional materials, conducting the formative evaluation, revising instructional materials and conducting the summative evaluation.

Similarly, Finney (2002) describes a framework of instructional materials development consisting of four stages of decision making. The stages are curriculum planning, ends/means specification, program implementation, and implementation in the classroom. They, however, believes that evaluation is not a stage in itself, but as necessary and integral part of each and all of the stages already mentioned.

Hyland (2003) suggests nine steps of materials development related to course materials namely consideration of the students (personal goals, proficiency levels, interest, etc.), consideration of learning context (duration, resources, relationship to other subjects), consideration of the target context (future roles of learners and the text and the tasks they need), establishment of course goals and objectives, planning the syllabus, devising units of work and lessons, creation or evaluation, and selection of materials, teaching the course, evaluation of learners.

All models might be applicable and well employed in developing language instructional materials. However, it is possible to make some modifications in the model of syllabus/materials development to suit particular instructional needs, purposes, and available resources.

In developing instructional materials, needs analysis is the first step that should be done. The intended purpose of conducting needs survey is to gather as much information as possible about the students or people that are involved in the program. Therefore, specifications made for materials should be based on detailed studies of the needs.

In concept, according to Hyland (2003), moreover, needs are actually an umbrella that embraces many aspects such as students' goals, proficiencies, and 
kinds of teaching they prefer. Besides, needs analysis is a necessary procedure to follow as it gives contribution in determining what materials to be of interest. To dig out the causes of the gap between the way we ideally think and the way we presently are, a needs assessment is required, as it is a problem identification process which focuses on the 'what it is' and 'what should be' in a particular situation.

It is a good idea to have criteria before an instructor uses a recorded material for his/her listening class. First, the curriculum is the basis of the materials development. It means that the materials can be used to reach the instructional objectives as stated in the curriculum and syllabus. In addition, two important characteristics of the syllabus, i.e. relevance and consistency should be reflected in the materials. Relevance means that the coverage, depth, level of difficulty, and materials sequencing are appropriate with the physical, intellectual, social, emotional and spiritual development level of the students. Consistency means that there is a consistent relation among basic competence, indicators, materials, instructional activities, learning sources, and assessment.

Second, the criteria are related to language, length, content, style, and speed of delivery, the style of delivery and the quality of the recording (Underwood, 1993b). The following is a brief description of the criteria. First, The language of the listening texts should be of the right level, as texts of the right level of difficulty combined with appropriate activities will develop not only the listening skill but also contribute to students' overall language learning. Listening has been identified as a valuable source of 'comprehensible input', and 'comprehensible input' contributes to the language acquisition. 'Comprehensible input' means the flow of language which contains elements already known plus some which have yet been mastered.

Second is related to the length of the texts. For most elementary and intermediate level, students listen attentively for anything more than about two minutes without a break of some sort. Of course, it is easier to pay attention longer if the subject matter of the listening text is particularly interesting, or if there is a specific task to do in relation to the text.

The third one is content. In early stages, it is important to use plain, straightforward content so that this can lessen the students' burdens. The burdens are the problems that the students have to cope with while they are listening. They do not know what sounds will occur, how fast the language is to be spoken, what the intonation signifies, what pauses are used for, or even whether the speaker is angry or pleased. To have plain, straightforward content, for example, texts should be avoided if they jump backward and forwards in time, deal with very abstract concepts are full of jargon words, or are not logically sequenced, etc. However, students should not be treated less 
mature intellectually. For example, adult learners should not use the same textbooks as young children and not expected to follow childish stories and make childish utterances.

The material should involve the students and make them want to listen. Funny stories and amusing pictures can be exploited to give great effects on language teaching but they should not be the only type of the material used. Moreover, it is not only the material that should be interesting to carry out the listening work, but also the instructors that should be creative so that students also enjoy what they are doing.

The outcome of this study provided the Listening Comprehension I class with available materials of relatively basic English listening which is compatible with the curriculum of English Department of IAIN Palangka Raya and facilitated instructors and learners' need. The process of teaching and learning listening then was expected to be more communicative, interactive and encouraging.

\section{METHOD}

This study made use of Research and Development (R\&D) design which developed and produced user-need-based products including instructorstraining materials, learning materials, sets of behavioral objectives, and media materials (Gay, 1990). The setting of the research took place of audio-visual supported language laboratory as the setup class of Listening Comprehension I in English Department of IAIN Palangka Raya. The research subjects were four listening instructors and the first-semester students (freshmen) who encountered fourteen meetings of this on-going semester.

The R\&D design covered a number of stages namely needs a survey, a material development which accounted for expert (and instructors) validation, revision, try out, revision and final product adapted from Gay (1990). The need survey was addressed to the listening instructors and the students to identify a gap between what students were able to do and what they needed to be able to do, and to collect information about a particular problem learners had been experiencing (Richards, 2002).

This phase included the analysis of situation and condition of the teaching and learning process using three data instruments namely questionnaire sheet, interview guide, and field notes. The questionnaire items collected information of students' backgrounds, learning experience in the class, and their opinion about listening. It was followed up by an interview with the listening instructors. The information about the availability and the need to the listening materials was obtained through this instrument which was strengthened by field notes. 
The second phase was developing a prototype of the listening materials. For this purpose, the researcher constructed a map of the materials which contained a unit topic, objectives, indicators, main activities, and extension activities. The topics were taken from the existing syllabus. The objectives were formulated based on the standard of competence and basic competence stated in the syllabus. The indicators were the reformulation of those stated in the syllabus. Main activities were set up based on the instructors' and students' suggestion. While the extension activities were other three macro skills-related listening activities based on the characteristics of the materials.

According to Hyland (2003, p. 99), the material development stage should undergo five ways such as (1) Addition which consisted of supplementing or extending what textbooks offers with extra readings, tasks, or exercises; (2) Deletion which was dealt with omitting repetitive, irrelevant, potentially unhelpful or difficult items; (3) Modification which concerned with rewriting rubrics, examples, activities, or explanations to improve relevance, impact, or clarity; (4) Simplification which focused on rewriting to reduce the difficulty of tasks, explanations, or instructions; and (5) Reorder was in parallel with changing the sequence of units or activities to fit more coherently with course goals.

Moreover, Underwood (1993b) stated that prototyped listening materials were developed on the basis of the need survey data which considered several aspects of difficulty-affected listening text namely language, length, content, style of delivery, delivery speed, suitability with the curriculum, practicality, clarity of the recording, level of difficulty, attractiveness, and effectiveness. The third phase was expert and instructors validation which was intended to meet criteria requirements of a good material in covered content, language, and style. (1) The content was supposed to lessen the students' learning burden (2) The language was supposed to be of the right level. (3) The style was supposed to have minimum varieties of speech at once.

Meanwhile, the four listening instructors gave validation on the suitability of the given materials towards the curriculum, length of the text, and speed of delivery. (1) The suitability of the materials towards the curriculum was related to its coverage and objectives. (3) The speed of the delivered text was supposed to be spoken at normal speed, not slowed down in an attempt to cheat the students. (4) The length of the text depended on how interesting the text was for the students and what specific tasks were employed in relation to the text. The result of the validation was in form of qualitative comments which consisted of three ranges, poor, fair, and good.

The next phase was the try-out of prototype materials. It had wings to find out its practicality, effectiveness, and clarity of the recording, attractiveness, 
speed of delivery and level of difficulty of the materials. The data obtained were useful to identify the problems and hindrances in applying the materials.

\section{FINDINGS}

\section{Expert Validation}

The expert stated that in general the tasks and activities focused more on teaching the students how to listen using three listening processes (bottom-up, top-down, and interactive). These were good for students' listening skills improvement.

\section{Instructor's Validation}

The instructors considered that the listening materials were quite good. The recorded materials on the compact disc were clear enough.

\section{Revision}

Based on the expert's and instructors' comments, judgments, and suggestion most of the materials, some sentences on the instructor's note, and some tasks need to be revised. In relation to the materials, the revision was done in terms of the length of the dialogues or sentences and the relationship of the materials with the students' context. In this case, the dialogues or sentences which were too long were shortened to make them brief. In addition, the materials which were not related to the students' context were changed with those related to the students' experiences. Moreover, some situational backgrounds were added to some dialogues or texts to make them clearer to the students.

Related to the instructor's note, some grammatical errors and unclear sentences were corrected e.g. (1) "Ask the students the answers" was corrected into "Ask the students to answer the questions"; (2) "Pause after each sentence to allow the students time to think and write" was changed into "Pause after each sentence to give the students time to think and make notes".

Some tasks were also revised in such a way to make them clearer to the students e.g. (1) the pictures were made clearer; (2) changing the type of task in Part 1 Unit 1 from writing the greetings the students listen from the recording into writing the greetings the students listen from the recording next to the available appropriate time.

Map of the materials was rearranged in a such a way that it was easier to read. Besides, time allotment of each unit was added in the map in order that the instructors knew how much time they needed to teach the materials of each unit. 


\section{The Data and the Analysis of the Try out}

The instructors were already so accustomed to conducting the English class in the language laboratory that it was not necessary to train them how to operate the language laboratory equipment.

The materials which were prepared in the form of CD recorded materials, instructor's guide, and student's worksheets were given to the instructors. They were told to read the instructor's guide before trying out the materials. They were not trained how to teach the materials since the researcher wanted to know whether the instructor's guide was understandable and easily implemented. However, the discussion to make the schedule of the try out was done by the instructors and the researcher. Considering the time allotment designed by the researcher and the real playing time of the recorded materials of each unit, the try out was scheduled to be conducted in 7 days.

\section{The First Try out}

The first try out was conducted. It was done to find out whether the recording and the instructor's guide were practical and whether the materials were effective to teach listening. The data obtained from the try out were divided into four parts i.e. from the observation, from the students' opinion on the materials, from the instructors' opinion, and from the students' grade of the tasks.

\section{Data Obtained from the Observation}

A number of important things which showed that the materials were effective to teach listening and that the recording and the instructor's guide were practical were noted as follows: (1) all of the participants were seriously joining the listening session, (2) in the process of teaching and learning, the instructors implemented the steps suggested in the instructor's guide easily; the extension activity, however, was not implemented, (3) the instructors could play the recording easily, (4) the students were brave enough to ask the instructors when they found difficult words, (5) the students learned unit 2 and 3 more enthusiastically because they could sing together and respond the instructions from the recording physically although some of them responded some instructions incorrectly, and (6) when the try out was completed, they said that they wanted to have listening class regularly.

\section{The Students' Opinion on the Materials}

The students were asked to answer the questions about the materials in terms of clarity of the recording, attractiveness, and speed of delivery after having finished learning each topic. No students considered that the materials 
were poor. Pertinent to the clarity of the recording, 50\% of the students considered that the materials were very good, $40.56 \%$ considered them good, and $9.44 \%$ considered them fair. In relation to the attractiveness, $23.89 \%$ of the students considered that the materials were very good, $59.44 \%$ considered them good, and $16.67 \%$ considered them fair. Concerning the speed of delivery, $23.89 \%$ of the students considered that the materials were very good, $41.11 \%$ considered them good, and 35\% considered them fair.

\section{The Result of the Students' Tasks}

The students' work of the tasks of each unit was collected from the try out. In addition, the classroom learning mastery should also be taken into consideration. It is approved by the instructors that if $80 \%$ of the students in a classroom already gain the minimum passing grade, the materials are considered appropriate for the students in terms of difficulty level and the classroom learning mastery is achieved. However, the students who have not achieved the minimum passing grade should join the remedial program.

From the result of the students' tasks, it was found out that most of the materials of Draft 2 have achieved the criteria of the appropriate materials for the students in terms of difficulty level. Only three topics were considered too difficult for the students. They were unit 3,10, and 14. The classroom learning mastery of unit 3 was $20 \%$, that of unit 10 was $0 \%$, and that of unit 14 was $30 \%$. Therefore, these three units needed revising in terms of difficulty level.

\section{The Instructors' Opinion}

After trying out each topic, the instructors were given an evaluation form of the product. They gave their opinion on two aspects i.e. the practicality and the effectiveness of the materials. The practicality is indicated by the ease of preparing and implementing the materials and the effectiveness is indicated by the usefulness of the materials for teaching listening skills.

All topics in terms of practicality and effectiveness were considered good by the instructors. They said that the recorded materials were easy to prepare and implement each part of the units was already recorded three times. In addition, they said that the instructor's guide was quite useful to direct them how to conduct the teaching and learning the process in the language laboratory. In term of effectiveness, they said that the materials could increase the students' motivation to learn English.

\section{Revision}

Based on the data obtained from the try out, it could be considered that the materials did not need revising in terms of clarity of the recording, 
attractiveness, speed of delivery, practicality, and effectiveness. In term of the difficulty level, however, unit 3,10, and 14 were necessary to be revised since the tasks of these units were too difficult for the students.

The revision was done by simplifying the tasks on the students' worksheet. For unit three, the revision was in the form of adding some words under the pictures. Therefore, after this unit was revised, the students only needed to write one or two words as a part of the instructions. Before it was revised, the students had to write the sentences under the pictures.

The revision of unit 14 was done for Part $1 \mathrm{~B}$ and Part 3. Part $1 \mathrm{~B}$ was revised by providing two options for each question. Part 3 was revised by giving numbers in the table showing how many items the students should put in it.

\section{The Second Try out}

The second try out was carried out only for units 3, 10, and 14 after they were revised. The result of the try out indicated that most of the students already achieved the minimum passing grade. It means that the classroom learning mastery was achieved.

For unit 3, all the students achieved the minimum passing grade. For unit 10 , the minimum passing grade was gained by $80 \%$ of the students. And for unit $14,90 \%$ of the students reached the minimum passing grade. From these data, these three units were considered appropriate for the students in term of the difficulty level. Therefore, no revision was needed.

\section{The Final Product}

The final product was presented after being validated by the expert and the instructors, revised based on the suggestions and comments from them, tried out, and revised accordingly. The product is prepared for semester 1 . It consists of 14 units. The product is in the form of one CD recorded materials, one instructor's guide, and the students' worksheet. The CD contains the recorded dialogues and texts of each unit. Each dialogue or text of each unit is recorded three times. Accordingly, the recorded materials are practical since the instructors will not need to replay the CD.

It contains the preface, list of contents, the general direction and specific direction of how to teach listening using the prepared materials, a map of the materials, 14 units with the objectives, pre-listening activity, whilst-listening activity, post-listening activity, an extension activity, typescript, and answers key in each unit. Map of the materials contains a topic, time allotment, objectives, indicators, main activities, and extension activity of each unit. 
Extension activity suggests that the activity of speaking or writing is integrated with the listening activity.

The suggested pre, whilst, and post-listening activities were developed following the principles of listening comprehension class. Some of the principles are (1) it is suggested that students make listening to the primary channel for learning new material; (2) it is good to activate top-level skills by having a discussion which calls up students' background knowledge; (3) before the students begin to listen, they should understand clearly what they are expected to do, and (4) the students listen to a text with a specific purpose.

With complete specification, the instructor's guide can facilitate instructors to conduct the process of teaching listening. They will not be burdened with a complicated preparation which often makes them reluctant to teach listening.

\section{DISCUSSION}

The result of the needs survey enlightened on a strong demand for the availability of appropriate listening materials which really taught the students' skills of listening comprehension instead of merely testing listening. As suggested by the research subjects, the prototyped listening materials appropriate for tertiary level students of English department heavily relied on the following findings.

According to the listening instructors, most of the students at this semester suffered a poor English proficiency although English learning had been experienced years before they proceeded to the English department. Their poor ability could be reflected from English vocabulary shortage, lack of English encounter, low learning motivation, appalling self-confidence etc. Some instructors assumed that less competitive high school background contributed to this condition.

Thus, based on the Stephen Krashen's concept of $i+1$, the materials given were supposed to be one level slightly higher than learners' current knowledge (Krashen \& Tracy, 1983). It would consider factors that considerably affect the understanding of the messages such as rate of speech delivery, the causal basis of speech, reduced forms, ungrammatical forms, pausing and speech errors, information content and cohesive device.

Second, the outline of the learning materials was supposed to include the definition of each chapter, taxonomy of listening skills, standard competence to achieve, learning objectives, suggested pre, whilst, and post-listening activities, listening skill focus, suggested autonomous learning, and listening exercises. It was assisted with teaching manual which contained a transcript of the listening tests, answer keys, and the recording podcasts. 
Third, the instructors and the students suggested a number of listening activities. They considered the following six activities appropriate i.e. matching, answering questions, determining true or false statement, completion, multiple choices, and pronunciation practice. The students proposed seven activities. They are multiple choices, matching, pronunciation practice, true or false statement, answering questions, summarizing, and completion.

Furthermore, the instructors preferred the recorded materials in an MP3 file to those on a cassette tape. According to them, MP3 file or commonly called podcast file was simple and efficient. With the existence of cellular phone with MP3 player facilities, the students were able to listen to podcasts frequently anytime and everywhere.

The prototyped listening materials facilitated 14 official meetings packed in 14 topical units which went upon the existing syllabus. Parts of the materials were adapted from several current English course books such as Timesaver Elementary Listening (Greet, n.d.), Basic Tactics for Listening (Richards, 2003), Interchange (Richards, 2005), Boost Listening (Renshaw, 2007), Listening Activities (Johnston, 2005), Listening Practice through Dictation, Listening Success (Byrne, 2009), Northstar Listening and Speaking (Merdinger \& Barton, 2009), Top-Up Listening (Cooney, et al., 2008), and English online websites like www.englishtips.org, www.manythings.org, www.youtube.com, www.voanews.com, etc.

\section{CONCLUSION}

The discussion and research findings can be summarized as follows: (1) the stages of the development of the listening materials were based on the Hyland's (2003) materials development model which was adapted into the stages employed in this study i.e. needs survey, developing the materials, expert and instructors validation, revision, try out of the materials, revision, and final product; (2) the product is in the form of compact disc recorded materials, an instructor's guide, and a students' worksheet; (3) the product consists of 14 units for semester 1 i.e. what's your job? meeting a new student, how do you feel?, come on, wake up!, can I try this on?, let's have a picnic, learning English through MP3, can you show me the place?, why didn't you see a doctor?, what's your hobby?, physical appearance, discovery listening technique, I became really sick, and I'd like to talk about schools; (4) the criteria for selecting materials are based on the existing syllabus and the criteria proposed by Underwood (1993b) i.e. language, content, style of delivery, length, speed of delivery, attractiveness, practicality, level of difficulty and effectiveness. (5) the materials are appropriate for the students since they are relevant to the students' need, interest, and level of 
students' English ability; (6) the listening activities can improve the students' motivation to learn English.

Some suggestions are presented in this part which might be taken into consideration for those who will conduct a similar study as well as for the instructors who will use the product. They are as follows: (1) other researchers can conduct further study to develop materials of Listening Comprehension II for semester 2, Listening Comprehension III for semester 3, and Listening Comprehension IV for semester 4 by employing the same model; (2) the instructors are suggested to use the product of this study since the listening activities are developed following the principles of listening comprehension class; and (3) the instructors should motivate the students not to worry if they do not understand every word since a listening task can be completed even when they miss some of the words.

\section{REFERENCES}

Adnan, A. (2014). Listening material development: Problems and challenges: A case of 'PPG SM-3t' at Universitas Negeri Padang. The $3^{\text {rd }}$ UAD TEFL International Conference 2014.

Brown, H. D. (2001). Teaching by principles: An interactive approach to language pedagogy. New York: Addison Wesley Longman, Inc.

Byrne, G. (2009). Listening practice through dictation, listening success. New York: Longman.

Cahyono, B. Y. (1997). Some essential issues in the teaching listening. In Cahyono, B. Y., Pengajaran Bahasa Inggris, Teknik, Strategi, dan Hasil Penelitian. (p.14). Malang: Penerbit IKIP Malang.

Call. M.E. (1995). Auditory short-term memory, listening comprehension and the input hypothesis. Tesol Quarterly, 19(4), 765-781.

Cooney, T., Cleary, C., \& Holden, B. (2008). Top-up listening. New York: Abax Ltd.

Dick, W., \& Carey, L. (2001). The systematic design of instruction. London: Scott, Foresman, and Company.

Fauzan, U. (2014). Developing EFL speaking materials for the second-semester students of STAIN Samarinda. Proceedings of $61^{\text {st }}$ TEFLIN International Conference. October 2014 (pp. 861-864). UNS Surakarta.

Finney, D. (2002). The ELT curriculum: A flexible model for a changing world. In Richards, J. C. \& Renandya, W. A. (Eds.), Methodology in Language Teaching: An Anthology of Current Practice (p. 74). Cambridge: Cambridge University Press.

Gay, L. R. (1990). Educational research: Competencies for analysis and application. Ohio: Merrill Publishing Company. 
Gebhard, J. G. (2000). Teaching English as a foreign and second language: A selfdevelopment and methodology guide. Ann Arbor: The University of Michigan Press.

Greet, J. (n.d.). Timesaver elementary listening. New York: Scholastic.

Harmer, J. (2007). How to teach English. New York: Longman.

Hyland, K. (2003). Second language writing. Cambridge: Cambridge University Press.

Johnston, O. (2005). Listening activities. New York: Eli.

Krashen, S. \& Tracy, T. (1983). The natural approach: language acquisition in the classroom. Oxford: Pergamon Press.

Merdinger, P. \& Barton, L. (2009). Northstar listening and speaking. Cambridge: Cambridge University Press

Renshaw, J. (2007). Boost listening. New York: Longman.

Richards, J. C. (1999). The language teaching matrix. Cambridge: Cambridge University Press.

Richards, J. C. (2002). Teaching listening. In Richards, J. C. \& Renandya, W. A. (Eds.), Methodology in Language Teaching: An Anthology of Current Practice (p. 235). Cambridge: Cambridge University Press.

Richards, J. C. (2003). Basic tactics for listening (2nd Ed.). Oxford: Oxford University Press.

Richards, J. C. (2005). Interchange. Cambridge: Cambridge University Press.

Rixon, S. (1993). Developing listening skills. London: Macmillan Publisher Ltd.

Rosyidah, A. (2002). Developing listening materials for teaching English at MAN Malang 1. Unpublished Thesis. Malang: State University of Malang.

Tomlinson, B. (1998). Materials development in language teaching. Cambridge: Cambridge University Press.

Underwood, M. (1993b). Effective class management: A practical approach. London and New York: Longman.

Zaenuri, M. (2008). Developing EFL listening materials for the students of the seventh grade of MTs Negeri Mojokerto. Unpublished Thesis. Malang: State University of Malang.

Zaenuri, M. (2015). A model of EFL listening materials development. Indonesian EFL Journal, 1(2), 119-130. 


\section{Authors' Brief CV}

Abdul Qodir obtained his doctoral degree in Education Evaluation from State Islamic University of Yogjakarta (2014). He is now a lecturer at the Faculty of Teacher Training and Education, IAIN Palangka Raya, Kalimantan Tengah, Indonesia. He is interested in the development of Research Methodology, Statistics, and English Language Evaluation.

Luqman Baehaqi obtained his master degree in English Education from State University of Malang (2010). He had experiences in teaching English. He is now an English lecturer at the English Department, IAIN Palangka Raya, Kalimantan Tengah, Indonesia. He is interested in the development of TEFL, TESOL, and SLA.

M. Zaini Miftah obtained his master degree in English Education from State University of Malang (2009). He had experiences in teaching English. He is now an English lecturer at the English Department, IAIN Palangka Raya, Kalimantan Tengah, Indonesia. He is interested in the development of TEFL, TESOL, CALL, and L2 Writing. 
Appendix: Questionnaire for the Students

\begin{tabular}{|c|c|c|c|c|c|c|}
\hline No & Statements & 1 & 2 & 3 & 4 & 5 \\
\hline 1 & $\begin{array}{l}\text { Of the four language skills, listening is the most } \\
\text { difficult to master }\end{array}$ & SD & $\mathrm{D}$ & $\mathrm{N}$ & A & SA \\
\hline 2 & I have good listening comprehension scores. & $\mathrm{SD}$ & $\mathrm{D}$ & $\mathrm{N}$ & $\mathrm{A}$ & SA \\
\hline 3 & $\begin{array}{l}\text { I frequently listen to spoken English (monolog, } \\
\text { dialogue, songs, etc). }\end{array}$ & SD & $\mathrm{D}$ & $\mathrm{N}$ & $\mathrm{A}$ & SA \\
\hline 4 & I feel easy to understand spoken English. & $\mathrm{SD}$ & $\mathrm{D}$ & $\mathrm{N}$ & $\mathrm{A}$ & SA \\
\hline 5 & $\begin{array}{l}\text { I identify my listening difficulties when I listen to } \\
\text { spoken English. }\end{array}$ & SD & $\mathrm{D}$ & $\mathrm{N}$ & $\mathrm{A}$ & SA \\
\hline 6 & $\begin{array}{l}\text { I have enough vocabulary to comprehend spoken } \\
\text { English. }\end{array}$ & SD & $\mathrm{D}$ & $\mathrm{N}$ & A & SA \\
\hline 7 & $\begin{array}{l}\text { I have good grammar competence to comprehend } \\
\text { spoken English. }\end{array}$ & SD & $\mathrm{D}$ & $\mathrm{N}$ & $\mathrm{A}$ & SA \\
\hline 8 & $\begin{array}{l}\text { I comprehend better whenever I have sufficient } \\
\text { background knowledge of what I am listening to. }\end{array}$ & SD & $\mathrm{D}$ & $\mathrm{N}$ & A & SA \\
\hline 9 & $\begin{array}{l}\text { Difference phonological system between English } \\
\text { and Bahasa Indonesia is the main factor of } \\
\text { listening comprehension difficulty }\end{array}$ & SD & $\mathrm{D}$ & $\mathrm{N}$ & $\mathrm{A}$ & SA \\
\hline 10 & $\begin{array}{l}\text { Teachers have taught appropriate learning } \\
\text { strategies to improve my listening } \\
\text { comprehension. }\end{array}$ & $\mathrm{SD}$ & $\mathrm{D}$ & $\mathrm{N}$ & $\mathrm{A}$ & SA \\
\hline 11 & $\begin{array}{l}\text { I always have strong motivation to improve my } \\
\text { listening comprehension skill. }\end{array}$ & $\mathrm{SD}$ & $\mathrm{D}$ & $\mathrm{N}$ & $\mathrm{A}$ & SA \\
\hline 12 & $\begin{array}{l}\text { Listening class atmosphere is encouraging and } \\
\text { motivating. }\end{array}$ & SD & $\mathrm{D}$ & $\mathrm{N}$ & $\mathrm{A}$ & SA \\
\hline 13 & I feel sleepy in listening class. & SD & $\mathrm{D}$ & $\mathrm{N}$ & A & SA \\
\hline 14 & $\begin{array}{l}\text { I recognize the meaning of words when I am } \\
\text { listening to English spoken. }\end{array}$ & SD & $\mathrm{D}$ & $\mathrm{N}$ & $\mathrm{A}$ & SA \\
\hline 15 & $\begin{array}{l}\text { I know the strategy to improve listening } \\
\text { comprehension skill. }\end{array}$ & $\mathrm{SD}$ & $\mathrm{D}$ & $\mathrm{N}$ & $\mathrm{A}$ & SA \\
\hline 16 & $\begin{array}{l}\text { The listening materials given by the teacher are } \\
\text { interesting. }\end{array}$ & SD & $\mathrm{D}$ & $\mathrm{N}$ & A & SA \\
\hline 17 & $\begin{array}{l}\text { The listening materials provided from cassettes } \\
\text { are effective and efficient }\end{array}$ & $\mathrm{SD}$ & $\mathrm{D}$ & $\mathrm{N}$ & $\mathrm{A}$ & SA \\
\hline 18 & $\begin{array}{l}\text { Listening materials given by the teachers are } \\
\text { fitting to my listening proficiency level. }\end{array}$ & SD & $\mathrm{D}$ & $\mathrm{N}$ & A & SA \\
\hline
\end{tabular}


Notes: $\mathrm{SD}=$ Strongly Disagree, $\mathrm{D}=$ Disagree, $\mathrm{N}=$ Neither Agree or Disagree, $\mathrm{A}=$ Agree, $\mathrm{SA}=$ Strongly Agree 